\title{
Aセッション 日本内科学会生涯教育講演会
}

\section{平成 11 年度}

\section{III. 内分泌·代謝 \\ 2. 体液調節：最近の進歩}

齊藤 寿一

Key words：バソプレシン, 下垂体後葉炎, 尿崩症, 低ナトリウム血症, アクアポリン2, バソプレシン拮抗薬

はじめに

体液調節系は生体の恒常性維持機構の基本と なるもので，多くの内分泌一腎因子が複合した 調節機能を果たしている. 近年, 分子生物学的 な手法によって体液調節系の生理と病態とが明 かになり，またそれを基盤にした診断一治療法 の開発も進められている。本稿では水とナトリ ウムの代謝異常を中心に体液調節の最近の進歩 を展望したい。

\section{1. 下垂体後葉炎}

視床下部の視索上核と室傍核で産生された抗 利尿ホルモン（バソプレシン, VP) は下垂体 後葉に転送, 貯蔵され血槳浸透圧の上昇や循環 血液量の減少に呼応して下垂体後葉から放出さ れる、VPは腎集合尿細管に作用してその水再 吸収を促し，抗利尿作用を発揮する.VP欠損 状態である尿崩症は多尿や高ナトリウム血症を 来す．尿崩症の原因は平成 7 年の厚生省研究班 の集計では表 1 の様に視床下部一下垂体後葉系 の器質的障害に由来する続発性尿崩症が $60.4 \%$ と最も多く、これに次いで原因の明らかでない 特発性㽷崩症が $38.6 \%$ となっている。この特発 性尿崩症の原因として, リンパ球性漏斗部一下 垂体後葉炎が注目されている。リンパ球性下垂

さいとうとしかず：自治医科大学内分泌代謝科
表 1、尿崩症の原疾㭧(厚生省特定疾患間脳下垂体障害 調查研究班 平成 7 年度報告書)

\begin{tabular}{|c|c|c|c|c|}
\hline & 男 & 女 & 翆 & $(\%)$ \\
\hline 特発性 & 123 & 138 & 261 & $(38.6)$ \\
\hline 家族性 & 3 & 4 & 7 & $(1.0)$ \\
\hline 続発性 & 214 & 195 & 409 & $(60.4)$ \\
\hline 胚茅腫 & 47 & 43 & 90 & 13.3 \\
\hline 頭蓋呕頭腫 & 43 & 49 & 92 & 13.6 \\
\hline 下垂体腫㴏 & 13 & 9 & 22 & 3.2 \\
\hline 転移性腫癁 & 4 & 3 & 7 & 1.0 \\
\hline 白血病 & 1 & 2 & 3 & 0.4 \\
\hline リンパ腫 & 2 & 0 & 2 & 0.2 \\
\hline その他の腫煬 & 29 & 21 & 50 & 7.4 \\
\hline サルコイドーシス & 0 & 1 & 1 & 0.1 \\
\hline ヒスチオサイトーシス X & 4 & 9 & 13 & 1.9 \\
\hline 外傷 & 14 & 7 & 21 & 3.1 \\
\hline 手術，その他(除 1 過性) & 41 & 26 & 67 & 9.9 \\
\hline 計 & 340 & 337 & 677 & $(100)$ \\
\hline
\end{tabular}

体後莱炎は1970年に持続性高ナトリウム血症を 伴った後葉機能低下症の 1 例において下垂体後 葉に著しいリンパ球の浸潤と線維化とを認め, 慢性下垂体後葉炎として初めて報告された1”. MRI (magnetic resonance imaging)を中心と した画像診断の進歩を踏まえて井村らは特発 性尿崩症の 9 症例において漏斗部から下垂体柄 にかけての腫大を認め，生検した 4 例ではリン パ球浸潤と線維化とを認め,リンパ球性漏斗 部一下垂体後葉炎と命名した。この病態はその 後多くの報告があり ${ }^{3)}$, 疾病経過から自己免疫 機構の関与が想定されており診断基準が研究班 
表 2.リンパ球性漏斗部下垂体後葉炎の診断基準(厚生 省特定疾患間脳下垂体機能障害調査研究班平成 10 年度 報告書)

I. 症候

多尿，多飲，口渴などの尿崩症に特有な症候を 呈する.

II. 検查所見

1. 中枢性尿崩症に合致する㭘查所見を呈する.

2. 画像検査で下垂体茎の限局的肥厚，または下垂 体後葉の腫大を認める，造影剂により，均一な 造影増強効果を認好。

3. 下垂体または下垂体茎の生検でリンパ球を中心 とした細胞浸潤，慢性炎症像を認める。

III. 参考所見

1. 下垂体前葉機能は保たれることが多い(注 1)。

2. 画像検查上の異常所見は自然経過で消退するこ とが多い.

IV. 除外規定

以下の疾患との篮別が必要である.

1. 胚細胞腫

2. 全身性肉芽腫疾患(サルコイドーシス, Wagener 肉芽腫症, Langerhans 細胞組織球(增

加)症など)

3. Tolosa-Hunt 症候群など下垂体周团組織からの 慢性炎症の波及

[診断基準]

確実例

I と】の1〜2およびNを満たすもの

I とロの 3 を满たすもの

（注 1）下垂体前葉機能低下を伴うものはリンパ球性 下垂体前葉炎を併発している場合がある。

から示されている(表 2). 最近de Bellisら゙は, 尿崩症のない自己免疫性内分泌疾患患者におい て視床下部VP細胞と反応する血清VP抗体を測 定し，下垂体後葉機能と対比して経過をおった。 その結果, 抗体陽性例に尿崩症を発症するもの があることを報告している，下垂体前葉には自 己免疫疾患として下垂体前葉炎が知られてお り，尿崩症を合併することもある，自己免疫性 下垂体前葉炎とリンパ球性漏斗部一下垂体後葉 炎とが同一の疾病単位に属するか否かについて は今後の検討課題となっている。

2. 老年者の水一ナトリウム代謝

入院患者について，低ナトリウム血症の発症

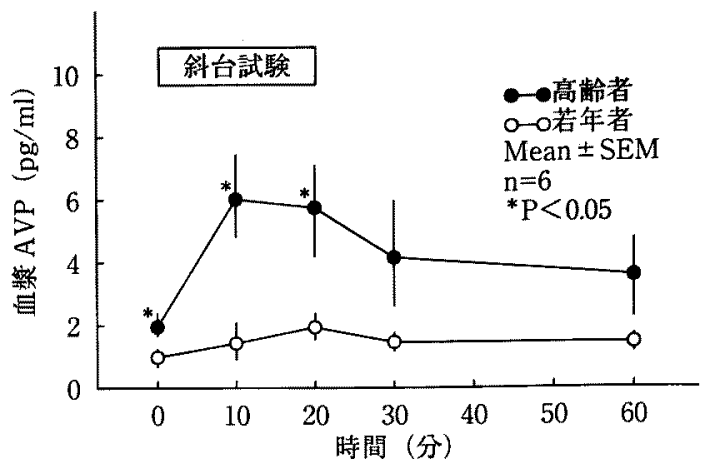

図 1.斜台試験が血竹AVPに及ほす倁果：頭部上 $60^{\circ}$

頻度と年齢との相関で見ると加歯と共に低ナト リウム血症の発症頻度が上昇することが報告さ れている5). 高齢者ではレニンーアルドステロ ン系の機能は低下し腎におけるナトリウム保持 力は低下する. その結果, 体内のナトリウムは 欠乏状態に陥りやすい，有効循環血液量の低下 に呼応して容量受容体を介した下垂体後葉から のVP分泌は充進し，水の貯留とともに血清ナ トリウム濃度は低下する. 加齢に伴う下垂体後 葉機能の変化を $60^{\circ} に$ 傾斜した斜台に正常人を 20分間固定した時の血圧と血中VP濃度の変化 からみると傾斜による循環調節自律神経機能 は，加齢と共に低下し血圧上昇反応は高齢者で 低下している6 。一方，血中VP濃度の変化をみ ると高齢者では若年者に比較してより大きな上 昇があり，有効循環血液量の低下によるVP分 泌反応は高齢者でむしろえ進していることが判 る（図 1 )。疾病状態にある高齢者では血圧調 節や体液量維持の低下による虚脱状態の出現が VPの相対的な分泌光進によって代償的に阻止 されているものと考元られる。

高齢者では肺炎や中枢神経系疾患などに合併 して低ナトリウム血症が発症しやすい。この時 の低ナトリウム血症ではナトリウムの補充に よっても尿中ナトリウムの排泄六進を伴い血清 ナトリウム濃度は上昇しにくい.またSIADH (syndrome of inappropriate secretion of antidiuretic hormone) の治療である, 水制限では 
しばしば脱水を招いて循環虚脱を来しやすい. この様な状態では鉱質コルチコイド薬であるフ ロリネフ ${ }^{\circledR}$ (9 -fuludrocortisone acetate) の投 与がしばしば低ナトリウム血症の治療に卓効を 示す7．高齢者におけるレニンーアルドステロ ン系の機能低下状態が代償されてナトリウムの 欠乏とVPの分泌圥進を介した水貯留状態を改 善させるものと考えられる。

\section{3. アクアポリン 2 の展開}

下垂体後葉から血中に分泌されたVPは腎集 合尿細管細胞の血管側細胞膜VP-V2受容体に結 合した後，刺激性グアニンヌクレオチド結合蛋 白を介してアデニルシクラーゼを賦活化し，細 胞内サイクリック AMPを上昇させる．細胞内 で上昇したプロティンキナーゼAが管腔側細胞 膜の水透過性を充進させ水再吸収を促進する過 程にVP感受性水チャネル，アクアポリン 2 (AQP2) が作動しており水代謝調節の指標と しても重要であることが明らかとなった，AQP 2 はヒトでは271個のアミノ酸からなる蛋白で 腎集合尿細管細胞内のAQP2mRNAとAQP2 蛋 白とは，VP投与や水制限による血中VP濃度の 上昇で増加しこれと共に尿浸透圧の上昇と尿量 の減少がおこる．逆に水負荷による血中VP濃 度の低下では，水利尿の発現とともにAQP2の mRNAと蛋白は腎集合管で隇少している．更 にこの様な血中VPの変動による尿濃縮の調節 はAQP2の産生のみでなく AQP2包含顆粒の細 胞内局在を変化させることが明らかとなっだ。 電顕上脱水を加えると AQP2 抗体で処理した金 粒子は管腔側細胞膜入と移動し, 一方, 水負荷 によって金粒子は細胞質へと移動する，同様の 細胞内のAQP2 免疫活性の移動は免疫組織学的 検討における蛍光局在によっても証明されてい る.VPの尿濃縮過程にはAQP2 蛋白の産生促 進と AQP2 蛋白の細胞内局在の管腔側への移動 を伴うことが明らかになっている.

$\mathrm{AQP} 2$ を包含する顆粒はこの椂に，体水分の

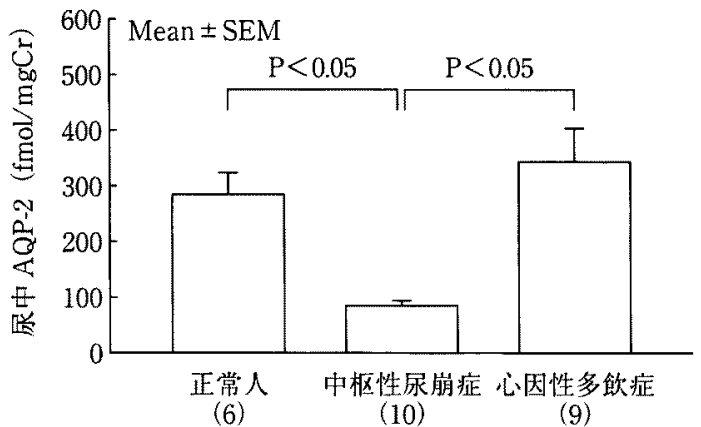

图 2. 正常人, 中枢性尿崩症及び心因性多饮症にお ける展中AQP-2 排泄

状態によるVP濃度に呼応して細胞質と管腔側 とを往復する「シャトル」または「リサイクリ ング」の移動があると诺えられ，更にその一部 は尿中へと排泄される，尿中への AQP2 排泄は $\mathrm{AQP2}$ 包含顆粒として排泄されており, 超遠心 沈渣にAQP2 免疫活性が検出され, 尿AQP2 は RIA (radioimmunoassay) で測定することが 出来る. 尿AQP2 の排泄は正常人に比較して中 枢性尿崩症患者では著しく低下しており，一方， 多尿患者であっても心因性多飲症の患者では中 枢性尿崩症患者に比較して高い水準にある（図 $2)^{9)}$ ，負荷試験においても中枢性尿崩症患者で は高張食塩水負荷後の尿中AQP2 の排泄上昇は 見られず，VP負荷によって上昇する，VPの腎 作用は専ら尿浸透圧を指標として評価されて来 たが，尿中 $\mathrm{AQP} 2$ 排泄量はVPの腎作用の新し い指標として臨床的にも有用であると考えられ る.

副腎皮質機能低下に伴うコルチゾル欠乏状態 では水利尿の低下があり，水負荷後の尿排泄量 は低下しており,低ナトリウム血症が持続する。 コルチゾル欠そ状態の水利尿低下の機序として は視索上核や室傍核におけるVP分泌立進，腎 血行動態の異常や腎フォスフォジエステラーゼ 活性の低下によるVPの作用立進などの機序が 考えられている。下垂体性副腎皮質機能低下症 における血中VP濃度は低浸透圧血症の状態と しては相対的に高值であるものの, 絶对値とし 


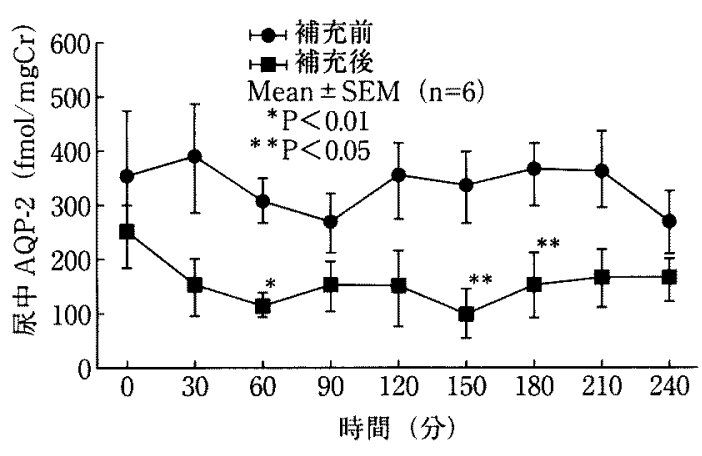

図 3、下垂体性副腎不全患者におけるハイドロコル チゾン補充前後の水負荷後尿中 AQP-2:0 分で経口水 負荷 $(20 \mathrm{ml} / \mathrm{kg})$

てはハイドロコルチゾン補充後と比較して差を 認めない。一方，尿中 AQP2 排泄量はハイドロ コルチゾン補充後の水利尿改善後に比して明ら かに上昇しており（図 3 ），コルチゾル欠乏状 態における水利尿の低下は腎におけるAQP2 の 産生六進に由来している可能性が示唆されてい る.

\section{4. バソプレシン拮抗薬の応用}

VPはアミノ酸 9 個からなり強い生物活性を 示すぺプチドで，腎尿細管水透過性促進を示す V2受容体作用と血管平滑筋の収縮を促すV1a受 容体作用を示す．このホルモンの受容体作用と 拮抗するVP拮抗楽は誘導体ぺプチドとして開 発されて来たが，ペプチドであるため注射薬に 限られ，作用の持続が短いこと，反復した投与 に適さないこと，動物種差が大きくラットの実 験成績からヒトでの効果を予測しがたいこと， などの久点があり臨床的に応用するには至らな かった、V2受容体拮抗薬としてOPC-31260, V 1a受容体拮抗薬としてOPC-21268が開発され, 更にV1aとV2の雨受容体拮抗薬としてYM-087 が開発された。OPC-31260は水制限後のラット に投与すると著しい水利尿効果を示し腎性尿崩 症に近い状態となる，四塩化炭素を皮下に投与 して奏験的に作成した肝硬変ラットでは，血獎 VP濃度は上昇し水負何後の水利尿は障害され
ている(10).この状態でOPC-31260を投与すると 水負荷後の利尿効果は正常対照ラットを上回 る.ヒトにおける投与でも水利尿は促進される. 低ナトリウム血症主徽とするSIADHの症例 にこの薬戍を投与すると, 水利尿の増強と共に 低ナトリウム血症は速やかに改善に傾く.OPC31260 のV2受容体拮抗作用は臨床的にも低ナト リウム血症の治療薬としいての有用性が示唆さ れる11!

\section{5.むすび}

体液調節についての最近の進歩を，下垂体後 葉ホルモン，特に水とナトリウムの代謝を中心 に展望した，著しい多尿を来す特発性尿崩症の 本態としては自己免疫で発症する下垂体後葉炎 が想定される。また高齢者において頻度が増加 する低ナトリウム血症は, 加龄とともにバソプ レシンが分泌立進しがちとなる事実と符合し, その成因を考える上で重要であろう，尿中AQP 2 测定はバソプレシンの腎作用を臨床的に評価 する上で重要な手がかりとなるものであり，尿 崩症と心因性多飲症との鑑別においてもAQP2 は臨床的に有用であると考えられる。また, 経 口的に投与可能なバソプレシン拮抗薬の開発は 各種の低ナトリウム血症の治療に有効であると 考えられる.

体液調節の領域では，これら水とナトリウム の代謝に加えて,カリウムゃカルシウムも含め, 特に先天性疾患の遺伝子異常が解明されてい る。特にBartter症候群, Gitelman症候群，あ るいは腎性尿崩症についてその遺伝子の異常が 示され，遺伝子診断が有用な手技となりつつあ る.

\section{文献}

1) Saito $T$, et al: Chronic hypernatremia associated with inflammation of the neurohypophysis. J Clin Endocrinol Metab 31 : 391-396. 1970.

2) Imura $\mathrm{H}$, et al : Lymphocytic infundibulohypophysitis as 
a cause of central diabetes insipidus. N Engl J Med 329 : 683-689, 1993.

3）齊藤寿一：リンパ球性下垂体後葉炎。ホと臨47(臨時 增刊号) : 12-16, 1999.

4) de Bellis A, et al : A longitudinal study of vasopressin cell antibodies, posterior pituitary function, and magnetic resonance imaging evaluations in subclinical autoimmune central diabetes insipidus. J Clin Endocrinol Metab 84 : 3047-3051, 1999.

5）齊藤寿一：低ナトリウム血症の臨床，日内会誌 80 ： 188-194. 1991.

6) Ishikawa $S$, et al : Involvement of arginine vasopressin and renal sodium handling in pathogenesis of hyponatremia in elderly patients. Endocrine J 43:101-108, 1996.

7) Ishikawa S, et al : Hyponatremia responsive to fludro- cortisone acetate in elderly patients after head injury. Ann Int Med 106 : 187-191, 1987.

8) Saito $T$, et al : Alteration in water channel AQP-2 by removal of AVP stimulation in collecting duct cells of dehydrated rats. Amer J Physiol 272 : F183-F191, 1997.

9) Saito $T$, et al: Urinary excretion of aquaporin-2 in the diagnosis of central diabetes insipidus. J Clin Endocrinol Metab 82 : 1823-1827, 1998.

10) Tsuboi $Y$, et al : Therapeutic efficacy of the non-peptide AVP antagonist $\mathrm{OPC}-31260$ in cirrhotic rats. Kidney Int 46 : 237-244. 1994.

11) Saito $T$, et al : Acute aquaresis by the nonpeptide vasopressin (AVP) antagonist OPC-31260 improves hyponatremia in patients with syndrome of inappropriate secretion of antidiuretic hormone (SIADH). J Clin Endocrinol Metab 82 : 1054-1057, 1997 